\title{
Time to Transition: Barriers and Opportunities to Farmer Adoption of Soil GHG Mitigation Practices in Dutch Agriculture
}

\author{
Anna Gomes ${ }^{1,2 *}$ and Pytrik Reidsma ${ }^{3}$ \\ ${ }^{1}$ Department of Earth System Science, Stanford University, Stanford, CA, United States, ${ }^{2}$ Centre for Sustainability Studies, \\ Lund University, Lund, Sweden, ${ }^{3}$ Department of Plant Sciences, Plant Production Systems, Wageningen University and \\ Research, Wageningen, Netherlands
}

OPEN ACCESS

Edited by:

Bruno José Rodrigues Alves, Brazilian Agricultural Research

Corporation (EMBRAPA), Brazi

Reviewed by:

Diana Marisa Silva Feliciano, University of Aberdeen,

United Kingdom

Libère Nkurunziza,

Swedish University of Agricultural

Sciences, Sweden

Greet Ruysschaert,

Institute for Agricultural, Fisheries and

Food Research (ILVO), Belgium

*Correspondence:

Anna Gomes

amgomes@stanford.edu

Specialty section

This article was submitted to Climate-Smart Food Systems,

a section of the journal

Frontiers in Sustainable Food Systems

Received: 06 May 2021

Accepted: 26 August 2021

Published: 27 September 2021

Citation:

Gomes A and Reidsma P (2021) Time

to Transition: Barriers and

Opportunities to Farmer Adoption of

Soil GHG Mitigation Practices in Dutch

Agriculture.

Front. Sustain. Food Syst. 5:706113.

doi: 10.3389/fsufs.2021.706113
As the second largest exporter of agricultural products worldwide, the Netherlands is a production hub, a leading example of high yields per hectare. However, this productivity includes intensive farming practices, placing a risk on the climate through the emission of greenhouse gases $\mathrm{N}_{2} \mathrm{O}$ and $\mathrm{CO}_{2}$ from soil. To meet global efforts, the Netherlands must reduce its climatic impact, including soil emissions, but the transition to alternative farming practices can be challenging. This research identifies the barriers and opportunities for arable farmers to adopt practices which mitigate emissions from agricultural soils, and consists of a literature review, informant interviews, and semi-structured interviews with farmers, policy-makers, and boundary organizations. Main findings are (1) a lack of awareness by farmers of their soil greenhouse gas production, and (2) six barriers and five opportunities for farmer adoption with placement of these findings into different steps of adoption. Critical barriers include economic challenges, personal mindset, on-farm complications, and the need to reconcile different stakeholders' rates of adoption. Opportunities lie with farmers becoming interested and able to quantify soil health, positive framing in the media, and policies or economic mechanisms to assist farmers. If the Netherlands can transition its farming system, the opportunities for the global food system could be significant.

Keywords: agricultural production, soil management, climate change, farmer adoption, the Netherlands, sustainability science

\section{INTRODUCTION}

Agricultural landscapes are multifunctional and must balance food production with providing regulation of water and greenhouse gases (GHGs) (Todman et al., 2019), while reconciling immediate needs and long-term tradeoffs (Foley et al., 2005). Since 1945, the Netherlands has been producing food for the world as the second largest exporter of agricultural products (Hoogervorst, 1993). However, this production has come with environmental consequences. As of 2017, "agricultural soils" contributed almost 30\% of agricultural sector GHGs (Ruyssenaars et al., 2019). From 2005 to 2013, the Netherlands had the highest agricultural soil GHG emissions per hectare in the European Union, at three times the EU28 average (Dace and Blumberga, 2016). It is possible to reconcile food security and climate change mitigation, but food secure countries like the Netherlands, need relatively higher mitigation targets (Gil et al., 2019). 
Although the production of soil GHGs is a complex system, Dutch arable farmers can take several soil management approaches to minimize soil $\mathrm{CO}_{2}$ and $\mathrm{N}_{2} \mathrm{O}$ emissions. While climatic and edaphic factors lead to variations in soil GHGs, including soil type, water content, temperature, nutrient availability, $\mathrm{pH}$ value, and land cover (Oertel et al., 2016), for the purposes of this research, a simplified list of agricultural soil GHG mitigation practices was compiled and referred to throughout the study (Table 1). Farmers are uniquely positioned to implement change in the system, as they determine on the ground implementation. However, according to Van Dijk et al. (2018), social, political, and economic challenges leave farmers struggling and left without options for adopting a new system. Overcoming these barriers, while enhancing existing opportunities, is key to widespread implementation.

A range of studies exist analyzing Dutch farmer adoption of innovation (Long et al., 2016), agri-environment schemes (Kleijn et al., 2001), nature inclusive farming (Runhaar, 2017), soil conservation practices (Bijttebier et al., 2014), and the addition of organic inputs (Hijbeek et al., 2018), however, none which exclusively focus on practices to mitigate soil emissions. Uncertainty of market conditions, environmental policy, and perceived production risks have been illustrated as barriers to adoption. For adoption of Integrated Arable Farming Systems (IAFS), the combined need for reduced input costs and inner transformation of farmers through an intensive learning process was critical for adoption (De Buck et al., 2008). Bartkowski and Bartke (2018) highlight the need to consider the "objective" characteristics of the farmer and farm, and the influence of environmental attitude and past experiences. Runhaar et al. (2016) discuss the importance of extrinsic characteristics of demand and legitimation from other actors. Lessons from other adoption studies are useful, but not sufficient in understanding the adoption of soil GHG mitigation strategies amongst arable farmers in the Netherlands.

Our research questions read: (i) how do Dutch arable farmers understand the impact of their management on soil GHGs, (ii) what are the barriers and opportunities in transitioning their practices to mitigation practices and (iii) how do the identified barriers and opportunities align with the established steps of farmer adoption. These questions are addressed through interviews with stakeholders, classifying adoption factors into barriers and opportunities, and analyzing these factors through the designed framework.

\section{MATERIALS AND METHODS}

\section{Data Collection}

A literature review was conducted to understand the socialenvironmental system. This work concentrates on three stakeholder groups within the Dutch arable farming sector, farmers [FM], policy-makers [PM], and boundary organizations [BO]. Boundary organizations are those which aim to institutionally bridge science and policy to communicate, translate, and mediate between actor groups on either side (Cash
TABLE 1 | Agricultural soil greenhouse gas mitigation practices and impacts.

\begin{tabular}{|c|c|c|}
\hline $\begin{array}{l}\text { Mitigation } \\
\text { practice }\end{array}$ & Description and soil GHG impact & References \\
\hline $\begin{array}{l}\text { Grow cover/catch } \\
\text { crops }\end{array}$ & $\begin{array}{l}\text { Growing crops in between cash crop } \\
\text { seasons. } \\
\text { Takes up excess nitrogen in the soil } \\
\text { and increases carbon inputs. }\end{array}$ & $\begin{array}{l}\text { Paustian et al., } \\
2019\end{array}$ \\
\hline $\begin{array}{l}\text { Implement } \\
\text { reduced/no tillage } \\
\text { systems }\end{array}$ & $\begin{array}{l}\text { Reduces physical intensity of } \\
\text { breaking up soil for seed bed } \\
\text { preparation. } \\
\text { Reduces carbon losses. }\end{array}$ & Ogle et al., 2019 \\
\hline $\begin{array}{l}\text { Increase nitrogen } \\
\text { use efficiency } \\
\text { (NUE) }\end{array}$ & $\begin{array}{l}\text { Matches applied fertilizer quantity and } \\
\text { plant demands, aiming to reduce total } \\
\text { nitrogen inputs. } \\
\text { Reduces excess nitrogen. }\end{array}$ & $\begin{array}{l}\text { Van Groenigen } \\
\text { et al., } 2010\end{array}$ \\
\hline $\begin{array}{l}\text { Add organic inputs } \\
\text { and surface } \\
\text { residue }\end{array}$ & $\begin{array}{l}\text { Applies compost/manure and leaves } \\
\text { crop residues/green manure on the } \\
\text { soil. } \\
\text { Increases carbon inputs. }\end{array}$ & $\begin{array}{l}\text { Paustian et al., } \\
\text { 2019; Witzgall } \\
\text { et al., } 2021\end{array}$ \\
\hline
\end{tabular}

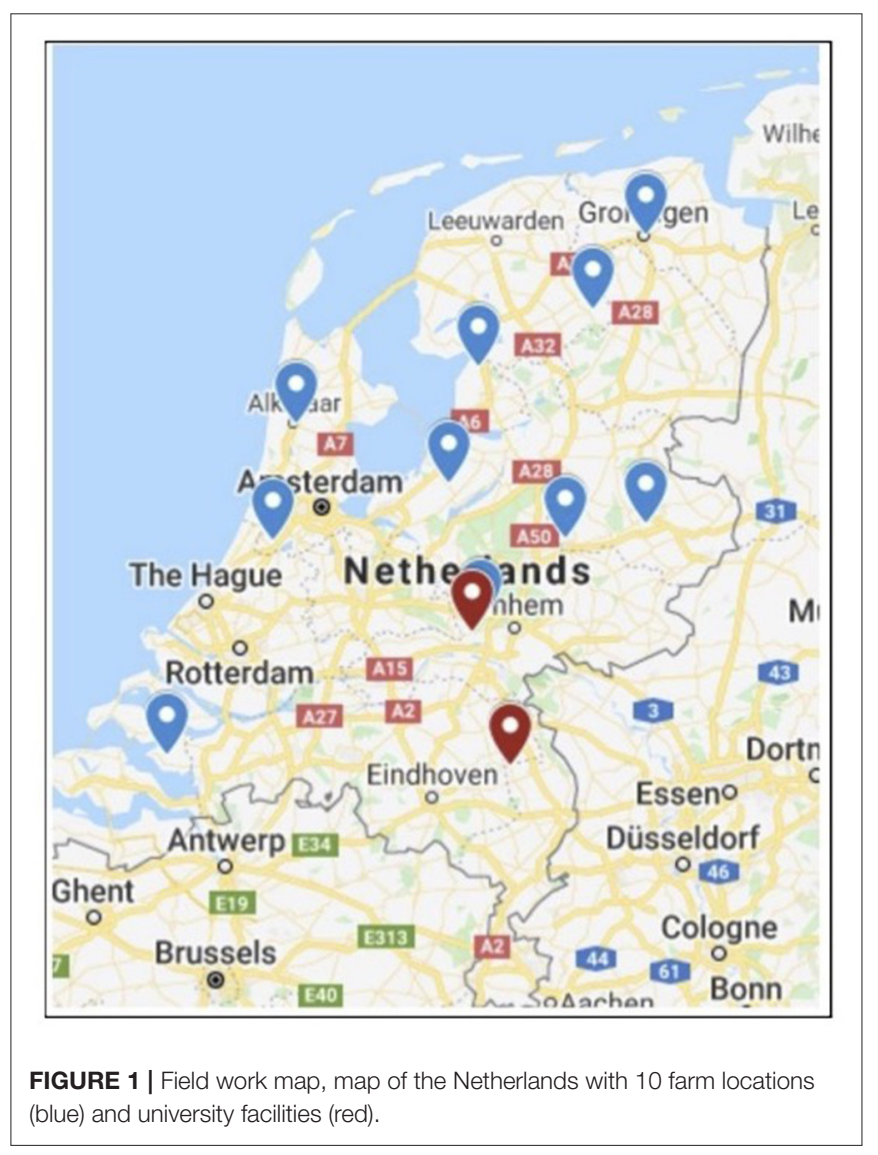

et al., 2002). Cash (2016) researched the critical role of boundary work in agricultural systems, noting that these stakeholders aid in navigating the complex decision making process in agriculture, as it is subject to shifting technological information and scientific advancements and inextricably linked to dynamic economic 
TABLE 2 | Farmer characteristics.

\begin{tabular}{|c|c|c|c|c|c|c|c|}
\hline \multirow[t]{2}{*}{ Characteristic } & \multicolumn{7}{|c|}{ Farmer } \\
\hline & 1 & 3 & 4 & 5 & 6 & 8 & 10 \\
\hline Size (ha) & 4 & 3.5 & 50 & 60 & 250 & 120 & $70-80$ \\
\hline Market Typology & Organic & Organic & Conventional & Organic & Conventional & Conventional & Conventional \\
\hline $\begin{array}{l}\text { Farm typology (De } \\
\text { Buck et al., 2008) }\end{array}$ & $\begin{array}{l}\text { Organic arable } \\
\text { farming }\end{array}$ & $\begin{array}{l}\text { Organic arable } \\
\text { farming }\end{array}$ & Conventional & IAFS & Conventional & Conventional & Conventional \\
\hline $\begin{array}{l}\text { Farm typology } \\
\text { (Therond et al., } \\
\text { 2017) }\end{array}$ & $\begin{array}{l}\text { Bio-input-based } \\
\text { farming system } \\
\text { and Alternative } \\
\text { food system }\end{array}$ & $\begin{array}{l}\text { Biodiversity-based } \\
\text { farming system } \\
\text { and Alternative } \\
\text { food system }\end{array}$ & $\begin{array}{l}\text { Chemical } \\
\text { input-based food } \\
\text { system and } \\
\text { Globalized } \\
\text { commodity-based } \\
\text { food system }\end{array}$ & $\begin{array}{l}\text { Bio-input-based } \\
\text { farming system } \\
\text { and Globalized } \\
\text { commodity-based } \\
\text { food system }\end{array}$ & $\begin{array}{l}\text { Chemical } \\
\text { input-based food } \\
\text { system and } \\
\text { Globalized } \\
\text { commodity-based } \\
\text { food system }\end{array}$ & $\begin{array}{l}\text { Chemical } \\
\text { input-based food } \\
\text { system and } \\
\text { Globalized } \\
\text { commodity-based } \\
\text { food system }\end{array}$ & $\begin{array}{l}\text { Chemical } \\
\text { input-based food } \\
\text { system and } \\
\text { Globalized } \\
\text { commodity-based } \\
\text { food system }\end{array}$ \\
\hline $\begin{array}{l}\text { Farming } \\
\text { generation }\end{array}$ & First & First & $\begin{array}{l}\text { Several, family } \\
\text { farm }\end{array}$ & $\begin{array}{l}\text { Several, family } \\
\text { farm }\end{array}$ & $\begin{array}{l}\text { Several, family } \\
\text { farm }\end{array}$ & $\begin{array}{l}\text { Several, Family } \\
\text { Farm }\end{array}$ & $\begin{array}{l}\text { Several, Family } \\
\text { Farm }\end{array}$ \\
\hline Crops & Mixed Vegetables & $\begin{array}{l}\text { Beans, soy, high } \\
\text { protein grains, and } \\
\text { wheat }\end{array}$ & $\begin{array}{l}\text { Sugar beets, } \\
\text { potatoes, onions, } \\
\text { winter wheat, } \\
\text { beets and barley }\end{array}$ & $\begin{array}{l}\text { Wheat, clover, } \\
\text { potato, onion, } \\
\text { spinach, pumpkin, } \\
\text { maize, parsley }\end{array}$ & $\begin{array}{l}\text { Bulbs, cabbage, } \\
\text { and potatoes }\end{array}$ & $\begin{array}{l}\text { wheat, sugar } \\
\text { beets, canola }\end{array}$ & $\begin{array}{l}\text { Potatoes, onions, } \\
\text { sugar beets }\end{array}$ \\
\hline$\%$ SOM & $3 \%$ & $3.4 \%$ & $3 \%$ & $4 \%$ & UK & $2-2.5 \%$ & $5 \%$ \\
\hline Soil type & Sandy & Sandy clay & Sea clay & Sea clay & Light sea clay & Heavy sea clay & Clay \\
\hline
\end{tabular}

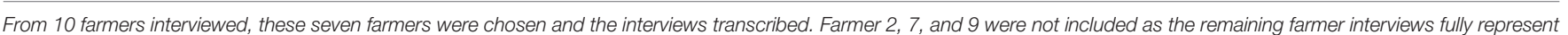
the presented opinions. 'Percent SOM' estimation and 'soil type' were provided by the farmers upon request. (UK: unknown; ha: hectare; IAFS: Integrated Arable Farming Systems).

and natural systems. Data collection included 31 interviews, consisting of 14 informants in addition to five [PM], two [BO], and $10[\mathrm{FM}]$. Informants include academic researchers, an agricultural extensionist, and an agri-business owner. [PM] work on the federal level of Dutch government and [BO] represent 35,000 agricultural entrepreneurs and employers, and 9,000 Dutch farmers (Figure 1). For the group of farmers, various "types" of [FM], as typologized according to De Buck et al. (2008) and Therond et al. (2017) (Table 2), and are geographically spread across the Netherlands (Figure 1) from farms ranging 3.5 to 250 hectares in size, with various crops grown on different soil types, bringing a diversity of arable farmer perspectives to the primary data set. Although particular farm and farmer characteristics could influence our results, we instead explore shared characteristics impacting soil GHG mitigation practice adoption, rather than variables which could be more or less relevant to specific groups of farmers. This research is based on a limited sample and does not represent the perspective of every Dutch arable farmer.

Supported by suggestions from the informant interviews [II] and the literature review, semi-structured interview questions were created (see Appendix). To address the first research question, interviews opened with a general question asking farmers which practices they do to reduce GHG production from their soils: "Do you currently use farming practices that reduce GHG emissions from your farm soils?". For the interviews, there was no distinction made between the individual greenhouse gases or a specification between direct or indirect emissions. Following the initial question concerning on-farm soil GHG mitigation, farmers were then informed of the practices (Table 1) and asked questions regarding their personal experience with adoption. All interviews were conducted in English, which carries a possible bias toward farmers who feel comfortable being interviewed, in addition to Dutch words lost in translation. Interviews were recorded with the aim of transcription, coding, and thematic content analysis.

\section{Data Analysis}

To address the first research question, the interview transcriptions were searched for knowledge of and connection to soil GHGs. To answer the second question, the transcriptions were coded for adoption barriers and opportunities. Transcriptions were coded with an iterative process and with the aim of identifying shared barriers and opportunities across all "types" of Dutch arable farmers. Based on the method conducted by Long et al. (2016), the resulting barriers and opportunities are thematically categorized into six barriers and five opportunities, listed in no particular order.

To address the third research question we created the $\mathrm{AD}$ Adoption Curve Framework (Figure 2; graphic adapted from Greene, 2018). Previously, researchers have analyzed the rate of farm practice adoption behavior, ranging from incremental adoption to sudden transformation (De Buck et al., 2008; Bartkowski and Bartke, 2018; Meuwissen et al., 2019) and hence the step design was deemed best fit for our analysis. Due to the framework representing the process farmers undergo in moving along the curve between the five stages (Table 3), from step A to step $\mathrm{D}$, we named the framework the AD Adoption Curve. Finally, the opportunities and barriers influencing adoption found in the second research question were placed by the authors along the curve (steps A, B, C, D). The framework is utilized to understand how the identified barriers and opportunities impact farmer adoption. 


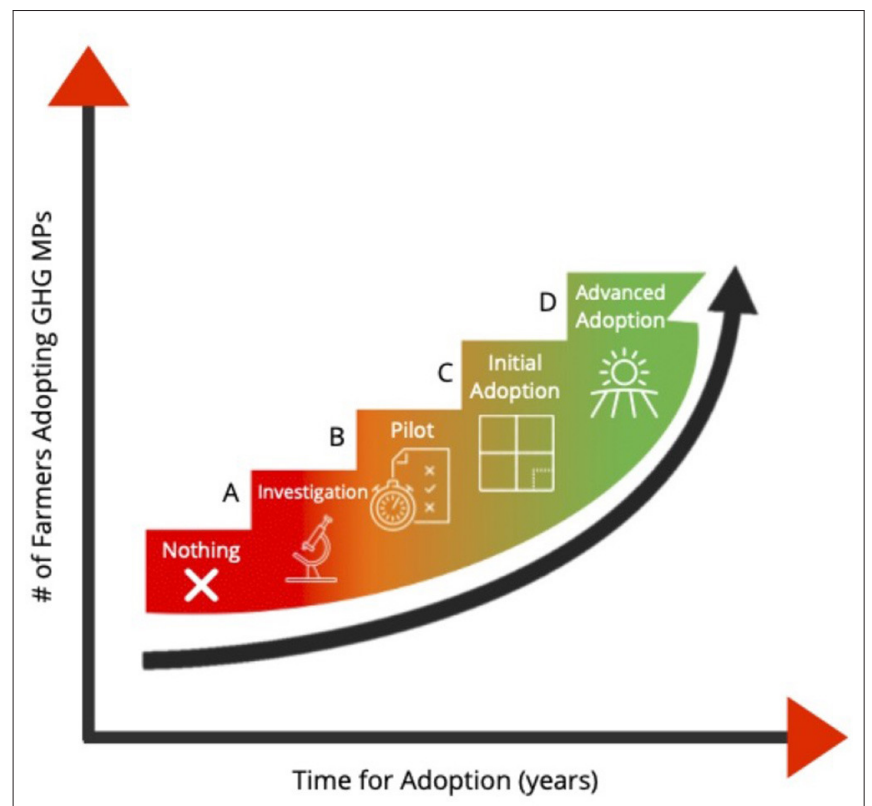

FIGURE 2 | AD adoption curve framework. The original image was created to model the adoption of artificial intelligence, and consisted of simply the main upward black arrow with the five stages, from "Nothing" to "Advanced Adoption." We redefined the stages in terms of farmer adoption of mitigation practices. Additionally, we added an x-axis (time), $y$-axis (number of farmers adopting MPs) and letters (A, B, C, and D) to represent the steps between each adoption stage. The considered stages include: Nothing, Investigation, Pilot, Initial Adoption, and Advanced Adoption, and the steps between each stage are A, B, C, and D. (Own Illustration, Adapted from: Greene, 2018).

TABLE 3 | AD Adoption Curve Framework Stage Descriptions (author defined).

\begin{tabular}{ll}
\hline Framework term & Description \\
\hline Nothing & $\begin{array}{l}\text { Farmer has no interest in the practices; 'not for me' } \\
\text { response } \\
\text { Farmer becomes interested in the practice and begins to } \\
\text { Investigation }\end{array}$ \\
look for more information \\
Pilot & $\begin{array}{l}\text { Farmer tries the practice on the farm, typically through a } \\
\text { pilot project coordinated through (environmental) }\end{array}$ \\
& $\begin{array}{l}\text { cooperatives or farmer organizations } \\
\text { Initial adoption }\end{array}$ \\
Advanced & partion of farm \\
adoption & Farmer executes full scale adoption of the practice on \\
& most, if not all, of the land in production
\end{tabular}

\section{RESULTS}

\section{Awareness of Soil Mitigation Practices}

Most farmers are not aware that their on-farm soil management practices affect soil GHG emissions. Farmers were asked which practices they employ to reduce GHG production from their soils.

The responses from the 10 farmer interviews are categorized as follows: a. Five farmers asked for clarification or responded with a confused facial expression until the interviewer added "for example, cover/catch crops, reduced/no tillage, etc." listing the previously defined soil mitigation practices from literature (Table 1).

b. Three farmers discussed practices they use to reduce $\mathrm{NH}_{3}$ gas production, for example injecting their manure instead of surface application. $\mathrm{NH}_{3}$ is not considered a GHG.

c. The remaining farmers mentioned reducing their use of farm machinery. This would decrease $\mathrm{CO}_{2}$ emissions due to the emissions saved from the internal combustion engines of the machinery, but this is considered indirect mitigation.

None of the farmers specifically mentioned efforts to reduce direct $\mathrm{CO}_{2}$ or $\mathrm{N}_{2} \mathrm{O}$ emissions from their soils. When asked if the agricultural sector plays a role in reducing national GHGs, the farmers referenced livestock emissions. BOs mentioned a lack of farm advisors with experience with soil health, and even fewer with knowledge of GHGs from soils in connection to specific farming practices.

\section{Barriers and Opportunities for Adoption}

Although farmers lack awareness as to the connection between their practices and soil GHGs, farmers are aware of the practices (Table 1), hence, the remaining interview questions were based on these practices, not soil GHG mitigation as a general strategy. Six barriers and five opportunities to adoption were identified.

\section{Barriers}

\section{Barrier 1. Personal Mindset}

Personal mindset refers to some farmers' hesitation to change their behavior. Many interviewees expressed that the farming community wants to maintain their existing system, as they originally learned. One farmer talked about one's comfort zone, "You have to be interested...first, you have to be motivated differently and you have to...do something new. That's the biggest challenge" [FM5]. Additionally, farmers feel they are already doing what they can for sustainability, by using organic amendments or manure on their farms and working more efficiently. According to an interviewee: "I think arable farmers... do a lot for sustainability. I don't know if we can do more. But maybe farmers act depending on the price we are paid for it" [FM4].

\section{Barrier 2. Nutrient Limits With Manure Challenges}

Farmers are conflicted between wanting to increase their livestock manure application to build their soil organic matter (SOM), and the limits set by policy for on-farm nitrogen and phosphorus application. Several farmers mentioned that they would prefer a larger budget for applying manure. One farmer stated: "So it's very difficult...we hope in the new policy (from the) national government that we... have more space for using manure. Because it's very good for our soil" [FM4]. None of the interviewees mentioned the distinction of $\mathrm{N}_{2} \mathrm{O}$ emissions between the synthetic and organic fertilizers, but most of them assumed that organic fertilizers are better for the environment. A few farmers linked increasing their organic manure application to storing more carbon in the soil. 


\section{Barrier 3. Balancing Demands}

Farmers are struggling to know how to balance and prioritize the environmental demands expected of them. Several mentioned the need to worry about monitoring biodiversity, planting nature strips, and reducing nutrient runoff and pesticide drift. According to an interviewee, "it's very difficult to monitor everything. Yeah or maybe not difficult, but it's expensive or time consuming" [FM6]. Trying to focus on yields and pest control, some farmers feel burdened to divert resources to proenvironmental efforts, especially when tradeoffs exist. One BO emphasized this point stating, "And then the farmer says, 'what is more important, to reduce the amount of methane or... nitrogen loss or (to) watch the ground or surface water' and then it's difficult for the farmers when they (feel) 'I'm doing one thing right' but then... society says 'you're doing two things wrong" [BO]. Farmers are feeling without direction and criticized regardless of their efforts. Furthermore, farmers expressed their frustration of disconnect with policy-makers. One farmer stated: "And farming is getting harder and sometimes rules are made up that we don't understand... We have a guest of the politics in the building and we explain something and they're flabbergasted" [F10].

\section{Barrier 4. Temporal Dilemma}

Most interviewees unexpectedly mentioned the concept of time (Table 4). "Time" is referred to as the time needed by farmers to change their practices, and often time to witness the results. Farmers expressed a feeling of being expected to change their practices too fast, with various time-related pressures. One farmer stated, "But I think... what politicians maybe want or would like is that the process goes faster" [FM5]. One farmer interviewee mentioned the need to test changes to their farm plan. Furthermore, soil is inherently slow to change, "Lot of positive effects. But it's not that if you start with minimum tillage now, that the next year you will have soil full of worms. It takes time" [FM8].

Several farmers mentioned that they are unsure if policies will change and what chemicals they will be allowed to use on their farm, making long-term planning difficult. According to an interviewee, "I already made the investment, and that's with a lot of things. If you can't look... at least five years ahead, then it's difficult to make a good plan" [FM8]. This uncertainty makes changing one's farming practices seem risky, both socially and financially. Several mentioned that they are concerned with the future ban of glyphosate. A chemical often used for clearing weeds in a reduced/no tillage system or to terminate cover/catch crops, two key soil mitigation practices. Connecting the temporal dilemma to the first barrier, shifting practices from one's own motivation might take longer, but the adoption will be more permanent and change long-term farm management.

\section{Barrier 5. Practical On-Farm Challenges}

Almost every farmer interviewee mentioned a practical challenge to shifting practices. Challenges typically embodied obstacles regarding compatibility issues between new practices and the farmers' soil, or their crops or available machinery. One farmer states, "It's difficult to do...seeding if you (use) minimum tillage. But I'm talking about my soils. It could be very different in
TABLE 4 | Temporal factors mentioned by interviewees.

\begin{tabular}{|c|c|c|}
\hline $\begin{array}{l}\text { Duration } \\
\text { (Years) }\end{array}$ & Temporal factor & $\begin{array}{l}\text { Interview } \\
\text { data }\end{array}$ \\
\hline 2 & Period of reduced yields with initial adoption & [FM8] \\
\hline 3 & $\begin{array}{l}\text { Project funding length, farmer cooperative } \\
\text { projects }\end{array}$ & {$[\mathrm{BO}]$} \\
\hline 4 & $\begin{array}{l}\text { Dutch Ministry of Agriculture changes } \\
\text { leadership and hence policies }\end{array}$ & [FM3] \\
\hline $4-5$ & Period between official soil tests & [FM1/FM6 \\
\hline $5-7$ & $\begin{array}{l}\text { Project funding length, Agri-environmental } \\
\text { schemes (AECMs) }\end{array}$ & {$[\mathrm{PM}]$} \\
\hline 6 & $\begin{array}{l}\text { Period of time between when adopt practice } \\
\text { and when see reduced inputs, for instance } \\
\text { nitrogen }\end{array}$ & [FM5] \\
\hline 10 & $\begin{array}{l}\text { Dutch Climate Agreement to meet the targets } \\
\text { of climate-friendly land use with 'carbon } \\
\text { storage in soil and vegetation' }\end{array}$ & {$[\mathrm{PM}]$} \\
\hline $10-20$ & $\begin{array}{l}\text { Opportunity for a change of management, } \\
\text { younger generation taking over the farm }\end{array}$ & [BO/PM] \\
\hline 15 & $\begin{array}{l}\text { Period of time it takes to achieve a } 1 \% \text { SOM } \\
\text { increase }\end{array}$ & {$[\mathrm{BO}]$} \\
\hline 20 & Period of use for new farm machinery & [FM3] \\
\hline $30-40$ & $\begin{array}{l}\text { Period of time the farm is under one's } \\
\text { management }\end{array}$ & {$[\mathrm{BO}]$} \\
\hline
\end{tabular}

Factors contributing to barrier four, the temporal dilemma. The table lists the various time related variables mentioned by interviewees, exhibiting the complex factors influencing the stakeholders' perspectives of speed for Dutch arable farmer transition.

other soils" [FM8]. Farmers stated that only certain crops are ready for the implementation of reduced/no tillage systems [FM4]. Farmers also expressed challenges with fertilization and weed management. For example, the internal conflict one faces between organic and synthetic fertilizers and the need to balance nutrient-release speed with avoiding soil compaction [FM5]. Several farmers mentioned weed management as the main barrier, specifically in reduced/no tillage systems. Linked to the temporal dilemma, many expressed their frustration over policies, mentioning that policy-makers design policies and expect farmers to develop the solutions without adequate resources in unrealistic time frames [FM10].

\section{Barrier 6. Economic Challenges}

A recurring theme mentioned is the lack of compensation for investing in the environment. Some mentioned that despite economic pressures they still consider soil mitigation practices important and try to adopt them, but monetary payments would increase their adoption scale. Some shared feelings of inequity in that they pay the costs, while society receives the benefits. One farmer interviewee stated, "So you take risks but you don't see added value in the products you produce" [FM5]. Currently, farmers only receive added value if they completely transition to biological farming, with no compensation for intermediate interventions [FM10]. One informant emphasized this point outlining that if farmers do not benefit by increased yields or reduced costs, they need to be economically compensated [II]. 


\section{Opportunities}

\section{Opportunity 1. Social Incentive}

Several farmers mentioned growing interest in soil mitigation practices after seeing neighbors, by visiting a practice farm nearby, or attending a field day. A novel platform to spread social incentive throughout the farming community is social media and online magazines or newspapers which increasingly discuss sustainability topics. One farmer states, "I got interested by reading articles" [FM4].

\section{Opportunity 2. New Focus on Soil Health}

Almost every farmer mentioned that soil quality is increasingly common as a discussion topic within farmer communities, one farmer stating, "I will tell you, the last few years we are getting aware" [FM6], when discussing his attention paid to the SOM. One interviewee mentioned that the biological movement has led conventional farmers to get interested in soil health [FM10]. This awareness might be connected to the recent inclusion of sustainable soil management, beyond soil's importance for maximizing yields, in vocational training and education [BO]. During the interviews, soil health was also discussed in the context of preparing one's farm for the future, "I'm more aware of the soil...in the beginning you try to maximize yields, but that's not always the good way to go for the future. Because your children far away, they have (to) also use the soil in a good way" [FM4]. While the initial inclination may be to think shortterm about maximizing crop yields, many farmers also consider the long-term.

\section{Opportunity 3. Mitigation as Climate Adaptation}

Without any direct inquiry, several farmers mentioned shifting their practices to prepare their farms for unexpected weather patterns; on-farm climate adaptation. Mitigation practices that improve soil structure provide many co-benefits for adapting to climate change. One example of this synergy is the adoption of reduced/no tillage. One farmer stated, "One of the reasons we stopped plowing was to build a robust system and what I experienced is that (when) we have a heavy rain shower...There's a fear of the fields to flood. But then within hours all the water is gone. So...the climate changes every year. We have to be ready." [FM5]. With reduced/no tillage, a practice that conserves soil structure and soil carbon, the soil can absorb standing surface water under a heavy rainfall, reducing crop damage and the time it takes to get in the field for planting. Another farmer mentioned a realization that beyond problems with "get(ting) the water off your fields", he also noticed that "when there is no rain, then you see you've got more problems with the drought" [FM8]. Farmers who discussed transitioning their practices due to adjustment for intense weather patterns did so without realizing they adopted soil mitigation practices. Finally, one interviewee commented that reduced/no tillage, although not the best practice for maximizing his yields, is helpful in buffering the flux of yields in especially wet or dry weather.

\section{Opportunity 4. Framing Farmers as a Solution}

There exists an opportunity to frame farmers as a solution to climate change as opposed to the problem. Several of the farmers mentioned their hesitation to turn on the national news channel due to what the media might be saying about farmers polluting the environment. This reveals the powerful role of the media to influence the feelings and behaviors of the farmers. This power could be utilized instead for positive media recognition, focusing on what farmers do to feed society and their efforts to mitigate soil GHGs. One farmer mentioned a "Need to focus on the front-runners" [FM5] who are working hard to reduce their environmental and climate impact, with a boundary organization saying, "But in our way we say farmers have the future, farmers have the solution to a lot of problems" [BO], referring to the ability of arable farmers to store carbon in their soils.

\section{Opportunity 5. Quantification of Soil Quality}

One of the reasons that soil quality is rarely found to be measured and translated into financial benefits is the lack of testing beyond a soil lab test conducted every 4 years. Stemming from one of the organizations and one young farmer interviewed, they excitedly discussed the novel developments for monitoring and measuring soil quality on-farm. One example is the Soil Passport tool, "I think the solution is to give insight in what you're doing at the moment and to quantify it. A lot of farmers actually are working on good soil management" [BO]. This and other innovations allow for translating soil health into a language in which farmers resonate with. During an informant interview, the interviewee relayed his experience that farmers are very quantitative in their reasoning and need to see evidence in the data before committing to new farm purchases.

\section{Along the Adoption Curve}

It is critical to know where these barriers and opportunities lie within the adoption spectrum to effectively focus intervention efforts and find key leverage points for systemic change. Most adoption factors fit to certain steps along the curve, with one barrier standing out as fundamental to the entire curve (Figure 3).

\section{Step A: From Nothing to Investigation}

Getting farmers originally interested in MPs requires heavy weight on social drivers. Farmers need to have a mindset open to exploring new options for their own farming operation, "and some (farmers) are saying well it's very nice that you do it, but it works for you. But I'm pretty sure it wouldn't work for me" [FM8] (Personal Mindset Barrier). However, opportunities to get farmers engaged in exploring MPs can be found amongst the farmer community (Social Incentive Opportunity) as well as within the broader news and media outlets (Framing Farmers as a Solution Opportunity).

\section{Step B: From Investigation to Pilot}

Bridging the gap between initial interest in MPs and trialing practices on one's farm requires a combination of awareness and understanding (New Focus on Soil Health Opportunity), in addition to the tools to push beyond the practical challenges with weeding, planting, fertilizing, and harvesting, which can come with on-farm implementation (Practical On-Farm Challenges Barrier). 


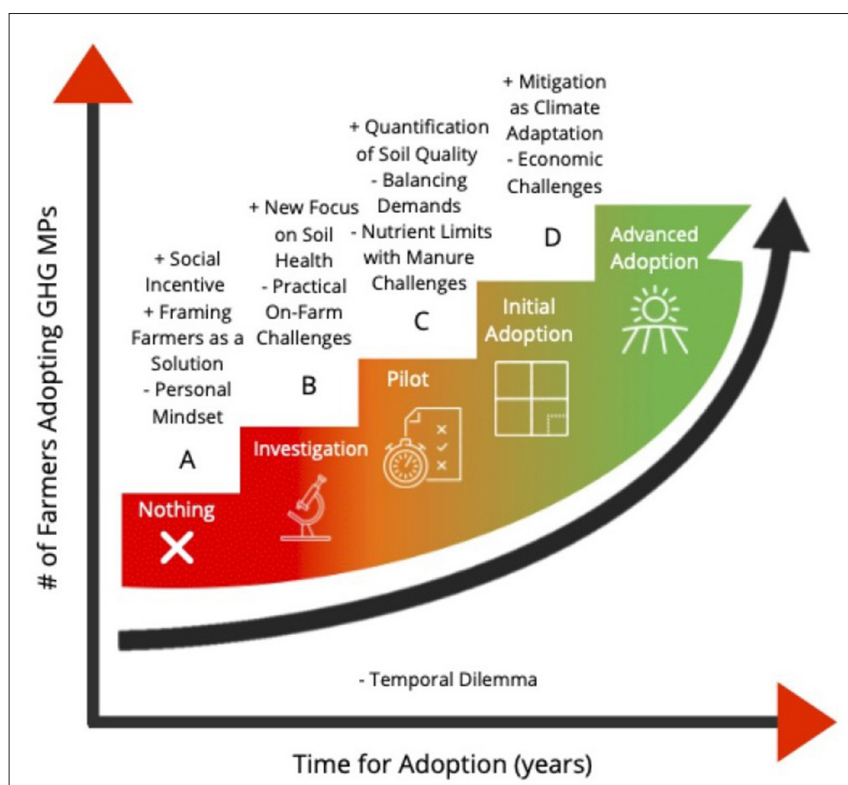

FIGURE 3 | AD adoption curve framework with results. The six barriers and five opportunities for MP adoption are placed at a specific step (A, B, C, D) along the curve, with one barrier applicable to all steps and can be found underneath the curve. The plus signs (+) refer to opportunities and the minus signs (-) refer to barriers. Own Illustration.

\section{Step C: From Pilot to Initial Adoption}

If farmers had the ability to measure and see that their soil quality improves while piloting, they could be more likely to continue the MP past the test period (Quantification of Soil Quality Opportunity). However, it becomes challenging for farmers to prioritize MPs over other pro-environmental practices (Balancing Demands Barrier). This is in addition to the nutrient budgets they face potentially being overdrawn if they expand this pilot scale to an initial adoption level area on their farm (Nutrient Limits with Manure Challenges Barrier).

\section{Step D: From Initial to Advanced Adoption}

In the final step of full farm adoption, the entire farming system is under revision. Farmers must consider the costs associated with scaling (Economic Challenges Barrier). One farmer states: "And every year we are doing a little bit more. Because in the first two years you have, some reduced yields" [FM8]. One incentive which could justify the advanced adoption is the need to build a resilient farm with high climate adaptation capacity, in order to maintain yields under heavy rain showers or fear of flooding (Mitigation as Climate Adaptation Opportunity).

\section{From $A$ to $D$}

Fundamental to transitioning along the entire curve is the speed of transition that the farmers are comfortable with compared to the expected or desired speed by other stakeholders (Temporal Dilemma Barrier).

\section{DISCUSSION}

\section{Within the Dutch Landscape}

Confirming previous findings by Runhaar et al. (2016), Dutch farmers feel stuck within the existing system. Regardless of their internal motivation to shift their practices (Bartkowski and Bartke, 2018) or personal mindset, there is a lack of farm advising for mitigating soil GHGs, leaving farmers without assistance. Despite current societal awareness of climate change, this research reaffirms past work by Oenema et al. (2001), finding that farmers are unaware of soil GHGs or measures to reduce them from their farms, requiring information and context-specific advice.

Our research results parallel conclusions from other farmer pro-environmental adoption literature, with personal mindset toward behavior change (Runhaar et al., 2016) as a barrier, and social incentive (Kuhfuss et al., 2016) as an opportunity. If farmers think the majority of farmers are adopting mitigation practices, they would be increasingly motivated by the "nudging effect” (Kuhfuss et al., 2016). Meuwissen et al. (2019) also found Dutch arable farmers experience "frustration about lack of long-term and stable policies," "performance of public goods is relatively poor," and "challenges which cannot be influenced are perceived to be most important (media attention, impact of pesticides)."

Although the temporal aspect of Dutch farmer adoption is largely missing from the literature, a global model was developed by Kuehne et al. (2017) of new agricultural practice uptake and found actual "time to peak adoption" to vary between 6 and 22 years. Additionally, researchers De Buck et al. (2008) have acknowledged a temporal delay between when farmers learn about an innovation and the actual adoption, an economic concept called Innovation Adoption Lag. Bartkowski and Bartke (2018) and Meuwissen et al. (2019) illustrate that farmers prefer incremental changes over longer periods of time rather than large, uncertain transformations, and the governance of this adoption shift should be flexible to allow for step-by-step adoption of practices. With an adaptive governance approach, it becomes possible to test policy ideas, and remove ineffective parts, while continuing to ask the users for feedback, keeping arable farmers central to the conversation (Folke et al., 2005).

\section{Tackling Barriers and Enhancing Opportunities}

Motivating farmers from "Nothing" to "Advanced Adoption" consists of several steps, each requiring different tools and approaches. Opportunities exist to encourage farmer movement along the adoption curve, but further action is required by policy-makers, farmer organizations, agricultural companies, researchers, and the media. Farmers are experiencing a shifting discourse toward a renewed interest in soil combined with the need to prepare their soils for climate change. Increasing focus is placed on the need to build a resilient farming system, for example by adding organic matter to arable soils to improve the water holding capacity (Smith and Olesen, 2010). Other actors in the system can highlight farmers "doing their part" for climate change mitigation and positive communication can reward those 
who are taking the extra financial risk. Kuhfuss et al. (2016) found that farmers acknowledged for their contributions are more likely to maintain practices without payment, in addition to the importance of communication framing, positive messages are more effective. In practice, this could materialize as media showcases of farmers working to protect the environment and reduce their GHG emissions, a tool of social recognition (Fraser, 2000) while incentivizing others. Farmers cannot visually see their soil GHGs, and they are surrounded by media and political priority placed on mitigating livestock emissions.

Economically, since many arable farmers grow crops which are sold to factories to end up as sugar in soft drinks or fries, it is difficult to gain added market value on growing crops with mitigation practices. Some informants shared that additional payments are unnecessary if farmers can reach higher yields, however the yield gap in the Netherlands is already very narrow for most crops (Silva et al., 2017). As a way for farmers to minimize personal investment in expensive machinery, they could hire contract workers to plant cover/catch crops or use reduced/no tillage machinery. Another option is to create a shared collective of farm machinery fit for executing soil mitigation practices, lowering the financial risk for each individual farmer. Combining the knowledge that many Dutch farmers think in quantitative terms with new methods to quantify soil quality, several economic incentive programs could become a possibility. Being paid according to performance indicators, for example the model of dairy farmers receiving loan discounts from Rabobank partnering with World Wildlife Foundation (WWF) Netherlands (https://www.rabobank.com/ en/about-rabobank/in-society/sustainability/articles/2017/

20170706-biodiversity-monitor.html), could be leveraged to reward arable farmers for soil emissions mitigation. Farmer interviewees mentioned that despite the fact that they do not get paid for adoption of GHG mitigation practices, many still find them important to adopt, but would increase the scale and degree to which they adopt if receiving additional payments. Shifting additional power to the member states, the revised EU Common Agricultural Policy (CAP) could provide the Dutch government with increased agency to financially compensate farmers for adopting certain soil management practices through eco-schemes or agro-environment climate measures (Baayen and van Doorn, 2020).

Currently, policies which explicitly address GHG mitigation from arable farmland are non-existent. Neither the Nitrate Directive, Water Framework Directive, or other EU directives contain specific soil GHG mitigation advice or policies for arable farms. There has been a political focus on nitrogen in the form of nitrate $\left(\mathrm{NO}_{3}\right)$, a water-soluble compound polluting groundwater and surface water (EU Water Framework Directive) or nitrogen in the form of ammonia $\left(\mathrm{NH}_{3}\right)$, a gas classified as air pollution (National Emissions Ceiling Directive). However, policies aiming to address nitrogen in the form of $\mathrm{N}_{2} \mathrm{O}$ are lacking. In order to meet the National Climate Agreement targeting a $49 \%$ reduction compared to 1990 levels by 2030 (https://www.government.nl/topics/climatechange/climate-policy), mitigation efforts will need to include reducing emissions from arable farmland.
As illustrated, farmers are increasingly attentive to their soil quality and health, however, may lack access to advisors with the appropriate knowledge, or may not clearly understand the biogeochemical mechanisms of the soil. Useful knowledge by boundary organizations must be credible, salient, and legitimate to effectively bridge scientific or technical knowledge to decision making (Cash et al., 2002), hence it will take time for these boundary agents to establish trust with farmers. One approach could be to develop a national boundary organization of Soil Extensionists, one for each Dutch province, in order to provide soil management advice that is focused for certain soils, climates, and farming systems. Existing funding "pilot" programs for most practices are short term, farmer cooperative projects lasting 3 years and Agri-Environment Scheme (AES) projects, common under the previous EU CAP, lasting 5-7 years. Funding ends once the project or program ends and the farmer is left to sacrifice future income or end the practice.

Reconciling time scales between what farmers perceive as a comfortable time to shift their practices and what policymakers expect from farmers, is critical. There exists a need to strike a sensitive balance between enhancing the speed of mitigation practice adoption for the benefit of climate change mitigation and the autonomy many farmers desire. This requires a combination of self-motivation by farmers to be interested and the economic and political systems which provide them the tools, while working to address the adoption barriers slowing their movement through the AD Adoption Curve.

\section{Next Steps}

As this research aims to catalyze the conversation surrounding the mitigation of GHGs from arable farmland in the Netherlands, there exists the need to further unpack adoption behavior. Future work could focus on $\mathrm{N}_{2} \mathrm{O}$ emissions and $\mathrm{CO}_{2}$ emissions individually or on certain farming practices, however, it's important to note the complexity of separating practices and gases. Other researchers have highlighted the need to consider the trade-offs which might be present between simultaneously mitigating $\mathrm{CO}_{2}$ and $\mathrm{N}_{2} \mathrm{O}$ emissions on agricultural landscapes (Lugato et al., 2018; Ashiq et al., 2021), or the influence of other management factors including irrigation (Kallenbach et al., 2010). A study conducted on sandy soils in the Netherlands found that various organic inputs have substantial, but uncertain, carbon accumulation and nitrogen emission tradeoffs (Bos et al., 2017). Further research is needed in order to understand the context-specific net soil GHG flux from cover/catch crops, reduced/no tillage, and other practices on arable farmland in the Netherlands.

Furthermore, research should be conducted on factors which could reverse the $\mathrm{AD}$ Adoption Curve, leading farmers to go from $\mathrm{D}$ to $\mathrm{A}$. This could include if certain chemicals are banned, an economic recession tightens profit margins, or as increasing impacts from climate change come to fruition. Additionally, part of understanding farmer adoption of soil GHG mitigation practices is the need to quantify where all arable farmers in the Netherlands fit along the AD Adoption Curve, from Step A to Step D. Monitoring and measuring progress toward meeting the green-blue objectives, as outlined in the Netherland's National 
Strategic Plan for the revised EU CAP (Baayen and van Doorn, 2020), would increase the capacity for setting indicator-based policies and the ability to track progress toward targets. Due to the variety of soil biophysical characteristics and crops cultivated, there are differences in the barriers and opportunities of adoption between European countries (Bijttebier et al., 2018; Hijbeek et al., 2019), however, shared lessons remain relevant. Dutch agriculture, seen as an example of successful production due to its high yields and use of technology, could positively influence global adoption of soil GHG mitigation practices.

\section{CONCLUSIONS}

This research sought to inform evidence-based and policyrelevant change by identifying the barriers and opportunities experienced by farmers in adopting soil mitigation practices. This work aims to fill a knowledge gap with an interdisciplinary sustainability science approach. Main challenges of mitigation practice adoption include unawareness by farmers of if and how GHGs are produced from farm soils, overcoming personal mindset and practical on-farm barriers, navigating existing political and economic systems, and reconciling temporal frameworks amongst stakeholders. There exists momentum to support farmers through the power of media recognition and shifting discourse, technological tools to measure and track soil quality, climate change mitigation and adaptation synergies. This research can improve our knowledge base for igniting climate change mitigation efforts and motivating work toward farming systems with healthy soils and thriving rural livelihoods within the Netherlands and beyond.

\section{DATA AVAILABILITY STATEMENT}

The raw data supporting the conclusions of this article will be made available by the authors, without undue reservation.

\section{ETHICS STATEMENT}

Ethical review and approval was not required for the study on human participants in accordance with the local legislation and institutional requirements. The patients/participants provided their written informed consent to participate in this study.

\section{AUTHOR CONTRIBUTIONS}

AG: conceptualization, methodology, field work, formal analysis, visualization, and writing - original draft. PR: conceptualization, methodology, supervision, and writing-reviewing and editing. All authors contributed to the article and approved the submitted version.

\section{FUNDING}

The field work was funded by the Mark E. Reed Scholarship sponsored by the Green Diamond Resource Company. These funds were awarded to the main author and were without stipulations as to spending. The publication fee has been generously waived by the editorial board of the FrontiersSustainable Food Systems, Climate-Smart Food Systems.

\section{ACKNOWLEDGMENTS}

Thank you to the numerous Dutch farmers who shared their valuable time and opinions with us, to Dr. Murray Scown, Dr. Juliana Dias Bernards Gil, Dr. Sara Brogaard, and Inge van de Wiel for providing guidance and advice in the methodology and fieldwork planning, and finally, thank you to the several academic researchers who provided their technical expertise as informational interviewees: Jan Willem van Groenigen, Gerard Velthof, Saskia Visser, Bert Rijk, Oene Oenema, Judith Westerink, Jan Verhagen, Bridgette Kroonen, Daan Verstand, Giuseppe Feola, Hens Runhaar, and René Verburg, and Thierry Stokkermans from Zip Drill. Additionally, we would like to thank the Mark E Reed Scholarship Foundation for contributing funding toward field work expenses.

\section{SUPPLEMENTARY MATERIAL}

The Supplementary Material for this article can be found online at: https://www.frontiersin.org/articles/10.3389/fsufs. 2021.706113/full\#supplementary-material

\section{REFERENCES}

Ashiq, W., Vasava, H., Cheema, M., Dunfield, K., Daggupati, P., and Biswas, A. (2021). Interactive role of topography and best management practices on $\mathrm{N}_{2} \mathrm{O}$ emissions from agricultural landscape. Soil Till. Res. 212:105063. doi: $10.1016 /$ j.still.2021.105063

Baayen, R.P., and van Doorn, A. (2020). Interventielogica voor de groenblauwe architectuur van het GLB; Borging van samenhang tussen doelen, maatregelen en monitoring. Wageningen, Wageningen Environmental Research, Rapport 3040. Available online at: https://edepot.wur.nl/536159

Bartkowski, B., and Bartke, S. (2018). Leverage points for governing agricultural soils: a review of empirical studies of european farmers' decision-making. Sustainability 10:3179. doi: 10.3390/su10093179

Bijttebier, J., Ruysschaert, G., Hijbeek, R., Werner, M., Pronk, A. A., Zavattaro, L., et al. (2018). Adoption of non-inversion tillage across

Europe: use of a behavioural approach in understanding decision making of farmers. Land Use Policy 78, 460-471. doi: 10.1016/j.landusepol.2018. 05.044

Bijttebier, J., Ruysschaert, G., Marchand, F., Hijbeek, R., Pronk, A., Schlatter, N., et al. (2014). “Assessing farmers' intention to adopt sustainable management practices for soil conservation across," in IFSA Conference proceedings.

Bos, J. F. F. P., Berge, H. F. M., Verhagen, J., and van Ittersum, M. K. (2017). Trade-offs in soil fertility management on arable farms. Agric. Syst. 157, 292-302. doi: 10.1016/j.agsy.2016. 09.013

Cash, D., Clark, W. C., Alcock, F., Dickson, N. M., Eckley, N., and Jäger, J. (2002). Salience, credibility, legitimacy and boundaries: linking research, assessment and decision making. SSRN Electron. J.. doi: 10.2139/ssrn.3 72280. Available online at: https://dash.harvard.edu/bitstream/handle/1/ 32067415/Salience_credibility.pdf?sequence $=4$. 
Cash, D. W. (2016). "In order to aid in diffusing useful and practical information": agricultural extension and boundary organizations. Sci. Technol. Human Values 26, 431-453. doi: 10.1177/016224390102600403

Dace, E., and Blumberga, D. (2016). How do 28 European Union Member States perform in agricultural greenhouse gas emissions? It depends on what we look at: application of the multi-criteria analysis. Ecol. Indic. 71, 352-358. doi: 10.1016/j.ecolind.2016.07.016

De Buck, A. J., Van Rijn, I., Roling, N. G., and Wossink, G. A. A. (2008). Farmers' reasons for changing or not changing to more sustainable practices: an exploratory study of arable farming in the Netherlands. J. Agric. Educ. Exten. 7, 153-166. doi: 10.1080/13892240108438817

Foley, J. A., Defries, R., Asner, G. P., Barford, C., Bonan, G., Carpenter, S. R., et al. (2005). Global consequences of land use. Science 309, 570-574. doi: $10.1126 /$ science. 1111772

Folke, C., Hahn, T., Olsson, P., ad Norberg, J. (2005). Adaptive governance of social-ecological systems. Annu. Rev. Environ. Resour. 30, 441-473. doi: 10.1146/annurev.energy.30.050504.144511

Fraser, N. (2000). Rethinking recognition. New Left Rev. 3:107.

Gil, J. D. B., Daioglou, V., van Ittersum, M., Reidsma, P., Doelman, J. C., van Middelaar, C. E., et al. (2019). Reconciling global sustainability targets and local action for food production and climate change mitigation. Glob. Environ. Change 59:101983. doi: 10.1016/j.gloenvcha.2019.101983

Greene, M. T. (2018). Available online at: https://www.marketintelligencellc.com/ tag/stephen-m-honig/ (accessed May 2, 2020).

Hijbeek, R., Pronk, A. A., Van Ittersum, M. K., ten Berge, H. F. M., Bijttebier, J., and Verhagen, A. (2018). What drives farmers to increase soil organic matter? Insights from the Netherlands. Soil Use Manag. 34, 85-100. doi: $10.1111 /$ sum.12401

Hijbeek, R., Pronk, A. A., Van Ittersum, M. K., Verhagen, A., Ruysschaert, G., Bijttebier, J., et al. (2019). Use of organic inputs by arable farmers in six agroecological zones across Europe: drivers and barriers. Agric. Ecosyst. Environ. 275, 42-53. doi: 10.1016/j.agee.2019.01.008

Hoogervorst, N. (1993). International influences on agricultural pollution in the Netherlands. Sci. Total Environ. 129, 137-155. doi: 10.1016/0048-9697(93)90167-5

Kallenbach, C. M., Rolston, D. E., and Horwath, W. R. (2010). Cover cropping affects soil $\mathrm{N} 2 \mathrm{O}$ and $\mathrm{CO}_{2}$ emissions differently depending on type of irrigation. Agric. Ecosyst. Environ. 137, 251-260. doi: $10.1016 /$ j.agee.2010.02.010

Kleijn, D., Berendse, F., Smit, R., and Gilissen, N. (2001). Agri-environment schemes do not effectively protect biodiversity in Dutch agricultural landscapes. Nature 413, 723-725. doi: 10.1038/35099540

Kuehne, G., Llewellyn, R., Pannell, D. J., Wilkinson, R., Dolling, P., Ouzman, J., et al. (2017). Predicting farmer uptake of new agricultural practices: a tool for research, extension and policy. Agric. Syst. 156, 115-125. doi: 10.1016/j.agsy.2017.06.007

Kuhfuss, L., Préget, R., Thoyer, S., Hanley, N., Le Coent, P., and Désolé, M. (2016). Nudges, social norms, and permanence in agri-environmental schemes. Land Econ. 92, 641-655. doi: 10.3368/le.92.4.641

Long, T. B., Blok, V., and Coninx, I. (2016). Barriers to the adoption and diffusion of technological innovations for climate-smart agriculture in Europe: evidence from the Netherlands, France, Switzerland and Italy. J. Clean. Prod. 112, 9-21. doi: 10.1016/j.jclepro.2015.06.044

Lugato, E., Leip, A., and Jones, A. (2018). Mitigation potential of soil carbon management overestimated by neglecting $\mathrm{N}_{2} \mathrm{O}$ emissions. Nature Clim Change. 8, 219-223. doi: 10.1038/s41558-018-0087-z

Meuwissen, M. P. M., Feindt, P. H., Spiegel, A., Termeer, C. J. A. M., Mathijs, E., Mey, Y., et al. (2019). A framework to assess the resilience of farming systems. Agric. Syst. 176:102656. doi: 10.1016/j.agsy.2019.102656

Oenema, O., Velthof, G., and Kuikman, P. (2001). Technical and policy aspects of strategies to decrease greenhouse gas emissions from agriculture. Nutr. Cycl. Agroecosyst. 60, 301-315. doi: 10.1023/A:1012601113751

Oertel, C., Matschullat, J., Zurba, K., Zimmermann, F., and Erasmi, S. (2016). Greenhouse gas emissions from soils-a review. Geochemistry 76, 327-352. doi: 10.1016/j.chemer.2016.04.002
Ogle, S. M., Alsaker, C., Baldock, J., Bernoux, M., Breidt, F. J., McConkey, B., et al. (2019). Climate and soil characteristics determine where no-till management can store carbon in soils and mitigate greenhouse gas emissions. Sci. Rep. 9, 1-8. doi: 10.1038/s41598-01947861-7

Paustian, K., Larson, E., Kent, J., Marx, E., and Swan, A. (2019). Soil C sequestration as a biological negative emission strategy. Front. Clim. 1:8. doi: 10.3389/fclim.2019. 00008

Runhaar, H. (2017). Governing the transformation towards "nature-inclusive" agriculture: insights from the Netherlands. Int. J. Agric. Sustain. 15, 340-349. doi: 10.1080/14735903.2017.1312096

Runhaar, H., Melman, T. C. P., Boonstra, F. G., Erisman, J. W., Horlings, L. G., de Snoo, G. R., et al. (2016). Promoting nature conservation by Dutch farmers: a governance perspective ${ }^{\dagger}$. Int. J. Agric. Sustain. 15, 264-281. doi: 10.1080/14735903.2016.1232015

Ruyssenaars, P. G., Coenen, P. W. H. G., Zijlema, P. J., Arets, E. J. M. M., Baas, K., Dröge, R., et al. (2019). National GHG Inventory Report (1990-2017), Table 5.1 and Table 5.11, the Netherlands. National Institute for Public Health and the Environment.

Silva, J. V., Reidsma, P., and van Ittersum, M. K. (2017). Yield gaps in Dutch arable farming systems: Analysis at crop and crop rotation level. Agric. Syst. 158, 78-92. doi: 10.1016/j.agsy.2017. 06.005

Smith, P., and Olesen, J. E. (2010). Synergies between the mitigation of, and adaptation to, climate change in agriculture. J. Agric. Sci. 148, 543-552. doi: $10.1017 /$ S0021859610000341

Therond, O., Duru, M., Roger-Estrade, J., and Richard, G. (2017). A new analytical framework of farming system and agriculture model diversities. A review. Agron. Sustain. Dev. 37, 1-24. doi: 10.1007/s13593-017-0 429-7

Todman, L. C., Coleman, K., Milne, A. E., Gil, J. D. B., Reidsma, P., Schwoob, M.-H., et al. (2019). Multi-objective optimization as a tool to identify possibilities for future agricultural landscapes. Sci. Total Environ. 687, 535-545. doi: 10.1016/j.scitotenv.2019.06.070

Van Dijk, J., Verburg, R., Runhaar, H., and Hekkert, M. (2018). Available online at: https://www.mejudice.nl/artikelen/detail/een-transitie-naarnatuurinclusieve-landbouw-van-waarom-naar-hoe (accessed February 27, 2020).

Van Groenigen, J. W., Velthof, G. L., Oenema, O., Van Groenigen, K. J., and Van Kessel, C. (2010). Towards an agronomic assessment of $\mathrm{N}_{2} \mathrm{O}$ emissions: a case study for arable crops. Eur. J. Soil Sci. 61, 903-913. doi: 10.1111/j.1365-2389.2009.01217.x

Witzgall, K., Vidal, A., Schubert, D. I., Höschen, C., Schweizer, S. A., Buegger, F., et al. (2021). Particulate organic matter as a functional soil component for persistent soil organic carbon. Nat. Commun. 12, 1-10. doi: $10.1038 /$ s41467-021-24192-8

Conflict of Interest: The authors declare that the research was conducted in the absence of any commercial or financial relationships that could be construed as a potential conflict of interest.

Publisher's Note: All claims expressed in this article are solely those of the authors and do not necessarily represent those of their affiliated organizations, or those of the publisher, the editors and the reviewers. Any product that may be evaluated in this article, or claim that may be made by its manufacturer, is not guaranteed or endorsed by the publisher.

Copyright (C) 2021 Gomes and Reidsma. This is an open-access article distributed under the terms of the Creative Commons Attribution License (CC BY). The use, distribution or reproduction in other forums is permitted, provided the original author(s) and the copyright owner(s) are credited and that the original publication in this journal is cited, in accordance with accepted academic practice. No use, distribution or reproduction is permitted which does not comply with these terms. 